\title{
Catalytic Activities of Transition Metal Phosphides for NO Dissociation and Reduction With CO
}

\author{
Z. Yao, ${ }^{\mathrm{a}, \mathrm{b},{ }^{*}}$ X. Qiao, ${ }^{\mathrm{a}}$ D. Liu, ${ }^{\mathrm{a}}$ Y. Shi, ${ }^{\mathrm{a}}$ and Y. Zhao ${ }^{\mathrm{a}}$ \\ ${ }^{a}$ College of Chemistry, Chemical Engineering and Environmental \\ Engineering, Liaoning Shihua University, Liaoning, PR China 113001 \\ 'Department of Chemistry, Dalian University of Technology, \\ Dalian 116024, PR China
}

doi: 10.15255/CABEQ.2014.2133

Original scientific paper

Received: October 19, 2014

Accepted: November 26, 2015

A series of metal phosphides (MoP, WP, $\mathrm{Co}_{2} \mathrm{P}, \mathrm{Fe}_{2} \mathrm{P}$ and $\mathrm{Ni}_{2} \mathrm{P}$ ) were synthesized by $\mathrm{H}_{2}$-temperature-programmed reduction method. Amongst these phosphides, $\mathrm{Fe}_{2} \mathrm{P}$ was found to show a considerably higher activity for NO dissociation than other phosphides. Herein, it was firstly used as a catalyst for $\mathrm{NO}$ reduction with $\mathrm{CO}$. Although the $\mathrm{Fe}_{2} \mathrm{P}$ catalyst showed an excellent activity for $\mathrm{NO}$ conversion to $\mathrm{N}_{2}$, there was a competition between $\mathrm{NO}$ reduction by $\mathrm{CO}$ and $\mathrm{Fe}_{2} \mathrm{P}$ oxidation by oxygen originated from $\mathrm{NO}$ dissociation. A complete equality of $\mathrm{NO}$ conversion and $\mathrm{NO}$ reduction degree can be obtained after increasing $\mathrm{CO}$ concentration in the system, which demonstrated that a catalytic redox cycle can be established on $\mathrm{Fe}_{2} \mathrm{P}$ catalyst, and hence in-situ oxidation of bulk $\mathrm{Fe}_{2} \mathrm{P}$ was avoided.

Key words:

$\mathrm{Fe}_{2} \mathrm{P}, \mathrm{NO}$ reduction, $\mathrm{NO}$ dissociation, catalytic redox cycle, bulk oxidation

\section{Introduction}

Transition metal phosphides are a group of compounds with interesting chemical/physical properties and potential applications in various fields, such as electronics, magnetism, photonics, catalysis, and so on ${ }^{1-4}$. In particular, metal phosphides (e.g. $\mathrm{MoP}, \mathrm{Ni}_{2} \mathrm{P}, \mathrm{WP}, \mathrm{Fe}_{2} \mathrm{P}$ and $\mathrm{Co}_{2} \mathrm{P}$ ) have been used as catalysts and extensively studied for hydrotreating reactions ${ }^{5-8}$. Among these phosphides, MoP, $\mathrm{Ni}_{2} \mathrm{P}$ and WP catalysts have shown significant promise in this regard because of their high activities and resistance to poisoning ${ }^{9-10}$. Therefore, they have been gradually explored as catalysts in many reactions, including $\mathrm{N}_{2} \mathrm{H}_{4}$ decomposition ${ }^{11,12}$, carbon dioxide reforming of methane ${ }^{13}$, hydrogen evolution reaction ${ }^{2,14}$ and hydrogen oxidation reaction ${ }^{15}$. However, compared with phosphides of metals $(\mathrm{Ni}, \mathrm{Mo}$ and $\mathrm{W}), \mathrm{Fe}_{2} \mathrm{P}$ has received far less attention due to its poor activity in hydrotreating reactions ${ }^{6}$. Recently, it has been found that a highly dispersed $\mathrm{Fe}_{2} \mathrm{P}$ catalyst on activated carbon showed better performance and stability than an iron catalyst ${ }^{16}$. Yet its general catalytic properties have not been explored, and this remains an area of considerable challenge.

In this study, we firstly report that $\mathrm{Fe}_{2} \mathrm{P}$ has a much higher catalytic activity for NO dissociation than phosphides of Ni, Mo, W and Co. In view of this unprecedented activity, $\mathrm{Fe}_{2} \mathrm{P}$ was selected as the

"Corresponding author: Zhiwei Yao, e-mail: mezhiwei@163.com, tel: $+86-24-56860968$ representative of phosphides to investigate the genuine nature of these catalysts for catalytic removal of NO. Although the activity and reaction mechanism of $\mathrm{Fe}_{2} \mathrm{P}$ catalyst for $\mathrm{NO}$ reduction with $\mathrm{H}_{2}$ had been studied in our previous letter ${ }^{17}$, some important details were still missing about the development of a catalytic cycle in phosphide-catalyzed NO reduction reaction. Currently, the $\mathrm{NO} / \mathrm{CO}$ reaction was used as a probe reaction to study the catalytic nature of $\mathrm{Fe}_{2} \mathrm{P}$ catalyst. The route for keeping the catalyst stable and active was further perfected.

\section{Experimental}

\section{Catalyst preparation}

Phosphides of metals (Mo, W, Co, Fe and Ni) were prepared in two steps. In the first step, phosphate precursors were prepared by combining stoichiometric quantities of metal salt $\left(\left(\mathrm{NH}_{4}\right)_{6} \mathrm{Mo}_{7} \mathrm{O}_{24} \cdot 4 \mathrm{H}_{2} \mathrm{O}\right.$, $\left(\mathrm{NH}_{4}\right)_{6} \mathrm{H}_{2} \mathrm{~W}_{12} \mathrm{O}_{40} \cdot \mathrm{nH}_{2} \mathrm{O}, \mathrm{Co}\left(\mathrm{NO}_{3}\right)_{2} \cdot 6 \mathrm{H}_{2} \mathrm{O}, \mathrm{Fe}\left(\mathrm{NO}_{3}\right)$. $9 \mathrm{H}_{2} \mathrm{O}$ or $\left.\mathrm{Ni}\left(\mathrm{NO}_{3}\right)_{2} \cdot 6 \mathrm{H}_{2} \mathrm{O}\right)$ and ammonium phosphate $\left(\mathrm{NH}_{4}\right)_{2} \mathrm{HPO}_{4}$ in sufficient distilled water to form a clear solution. In the case of $\mathrm{Ni}$ and $\mathrm{Co}$, several drops of nitric acid were needed to give rise to homogeneous solution. Then the solution was evaporated to dryness and calcined in air at $500{ }^{\circ} \mathrm{C}$ for $5 \mathrm{~h}$. In the second step of preparation, the phosphate precursors were converted into phosphides according to $\mathrm{H}_{2}$-temperature-programmed reduction procedure described by Prins and co-workers ${ }^{6}$. Typical- 
ly, about $2.0 \mathrm{~g}$ of phosphate precursor was placed in a micro-reactor and a flow of $\mathrm{H}_{2}\left(150 \mathrm{~cm}^{-3} \mathrm{~min}^{-1}\right)$ was introduced into the system. The temperature was increased from room temperature (RT) to $650{ }^{\circ} \mathrm{C}$ at a rate of $1{ }^{\circ} \mathrm{C} \mathrm{min}^{-1}$, where it was held for $2 \mathrm{~h}$ before quenching to RT in a flow of $\mathrm{H}_{2}$. Finally, the material was passivated in $1 \% \mathrm{O}_{2} / \mathrm{Ar}$ for $12 \mathrm{~h}$ before it was exposed to air.

\section{Catalyst characterization}

XRD examination was performed using an $\mathrm{X}$-ray diffractometer (Rigaku D-Max Rotaflex) with $\mathrm{Cu} K \alpha$ radiation $(\lambda=1.5404 \AA)$ in the $2 \theta$ range from 20 to $90^{\circ}$ at a step size of $0.06^{\circ}$. The sample particle size was estimated according to the Scherrer formula. The BET surface areas of passivated samples were measured on an ASAP 2010 instrument. The $\mathrm{N}_{2}$ gas was used for standard five-point BET surface area measurements. A temperature-programmed surface reaction (TPSR) experiment was performed on a flow reaction system. The catalyst $(0.4 \mathrm{~g})$ was pretreated in $\mathrm{He}$ flow at $500{ }^{\circ} \mathrm{C}$ for $1 \mathrm{~h}$, and then cooled to $150{ }^{\circ} \mathrm{C}$. After thermal stability was reached, the temperature was raised to $500{ }^{\circ} \mathrm{C}$ at $15{ }^{\circ} \mathrm{C} \mathrm{min}{ }^{-1}$ in $1 \% \mathrm{NO} / 1 \% \mathrm{CO} / \mathrm{He}\left(50 \mathrm{~cm}^{-3} \mathrm{~min}^{-1}\right)$. The effluent gases were continuously monitored with a mass spectrometer (MS, HP G1800A) for the analysis of masses $(M)=30(\mathrm{NO}), M=32\left(\mathrm{O}_{2}\right)$ and $M=28\left(\mathrm{~N}_{2}\right.$ or $\left.\mathrm{CO}\right)$, and an infrared absorption spectrometer (IRAS, SICK-MAIHAK-S710) for that of $\mathrm{N}_{2} \mathrm{O}, \mathrm{CO}$ and $\mathrm{CO}_{2}$.

\section{Catalyst activity}

The catalytic activity was measured using a $6.0 \mathrm{~mm}$ (o.d.) silica reactor by feeding a gas mixture of $0.1 \% \mathrm{NO} / 0-0.3 \% \mathrm{CO} / \mathrm{He}$. Typically, $0.4 \mathrm{~g}$ of catalyst was loaded onto a plug of silica wool, and the temperature of the catalyst bed was measured with a thermocouple inserted directly into the bed. The catalyst was pretreated in pure $\mathrm{He}$ at $400{ }^{\circ} \mathrm{C}$ for $1 \mathrm{~h}$ before the reaction. The reactants passed over the catalyst at a flow rate of $20 \mathrm{~cm}^{3} \mathrm{~min}^{-1}$, the corresponding $\mathrm{W} / \mathrm{F}$ was $1.2 \mathrm{~g} \mathrm{~s} \mathrm{~cm}^{-3}$. The effluent gases were monitored by online GC (HP 5890) using a molecular sieve $5 \mathrm{~A}$ column $(3 \mathrm{~m}, \phi 4)$ with a thermal conductivity detector (for the analysis of $\mathrm{O}_{2}, \mathrm{~N}_{2}, \mathrm{CO}$ and $\mathrm{NO}$ ), as well as a mass spectrometer (MS, HP G1800A) and an infrared absorption spectrometer (IRAS, SICK-MAIHAK-S710) (for that of $\mathrm{CO}_{2}, \mathrm{~N}_{2} \mathrm{O}$ and other possible nitrogen oxides).

\section{Results and discussion}

XRD patterns of the as-prepared phosphides of metals (Mo, W, Co, Fe and Ni) are shown in Fig. 1.

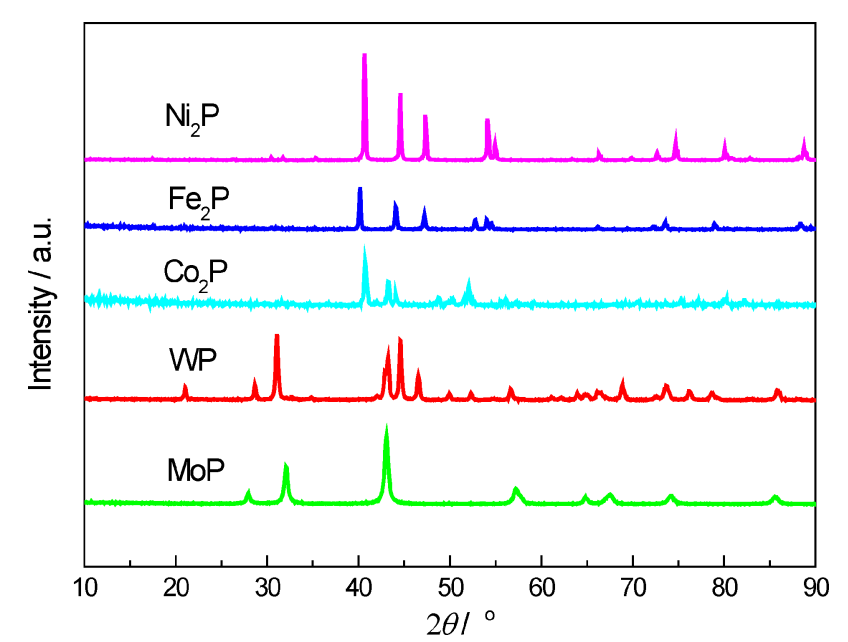

Fig. 1 -XRD pattern of as-prepared MoP, WP, $\mathrm{Co}_{2} P, \mathrm{Fe}_{2} P$ and $\mathrm{Ni}_{2} \mathrm{P}$ catalysts

Table 1 -Characterization results of samples

\begin{tabular}{c|c|c|c|c}
\hline Sample & $\begin{array}{c}\text { Crystalline } \\
\text { phase }\end{array}$ & $2 \mathrm{q} /{ }^{\circ}$ & $\begin{array}{c}\mathrm{BET} \text { area/ } \\
\mathrm{m}^{2} \mathrm{~g}^{-1}\end{array}$ & $\begin{array}{c}\text { Particle } \\
\text { size/nm }\end{array}$ \\
\hline $\mathrm{MoP}$ & $\mathrm{MoP}$ & $28.1,32.2,43.2,57.3$ & 5.1 & 21 \\
$\mathrm{WP}$ & $\mathrm{WP}$ & $31.2,43.3,44.7,46.7$ & 5.7 & 32 \\
$\mathrm{Co}_{2} \mathrm{P}$ & $\mathrm{Co}_{2} \mathrm{P}$ & $40.9,43.4,44.2,52.3$ & 4.9 & 42 \\
$\mathrm{Fe}_{2} \mathrm{P}$ & $\mathrm{Fe}_{2} \mathrm{P}$ & $40.3,44.2,47.3,52.9$ & 3.6 & 36 \\
$\mathrm{Ni}_{2} \mathrm{P}$ & $\mathrm{Ni}_{2} \mathrm{P}$ & $40.8,44.7,47.4,54.3$ & 3.9 & 33 \\
\hline
\end{tabular}

The peak positions were consistent with the crystalline phases listed in Table 1 . There were no metal phosphates/oxides, and no signal of phosphide phases other than that of the observed one, indicating that the materials were phase-pure. Table 1 also summarizes the textural properties of these phosphides. All the phosphides obtained had lower surface area, from 3.6 to $5.7 \mathrm{~m}^{2} \mathrm{~g}^{-1}$. The crystal sizes were calculated by the Scherrer formula based on XRD peak broadening, indicating dimensions of the order 21-42 nm.

Subsequently, the catalytic activity of these materials was evaluated for NO dissociation, and the results are shown in Fig. 2. It can be observed that, over WP, MoP, $\mathrm{Fe}_{2} \mathrm{P}, \mathrm{Co}_{2} \mathrm{P}$ and $\mathrm{Ni}_{2} \mathrm{P}$ catalysts, the $\mathrm{NO}$ conversion to $\mathrm{N}_{2}$ was about $0.003,0.004$, $0.037,0.013$ and $0.001 \mu \mathrm{mol} \mathrm{g}$ cat $^{-1} \mathrm{~s}^{-1}$ at $400{ }^{\circ} \mathrm{C}$, respectively. Obviously, amongst this series of phosphides, $\mathrm{Fe}_{2} \mathrm{P}$ was found to exhibit a considerably higher activity than other phosphide catalysts. However, it was worthy to note that the $\mathrm{O}_{2}$ generated in NO decomposition was not detected in the reactions. Our previous study had proved that oxygen species produced during NO decomposition was not released into the gas phase as $\mathrm{O}_{2}$ but captured by phosphide catalyst, which led to bulk oxidation of phosphide ${ }^{17}$. It was suggested that a catalytic redox 


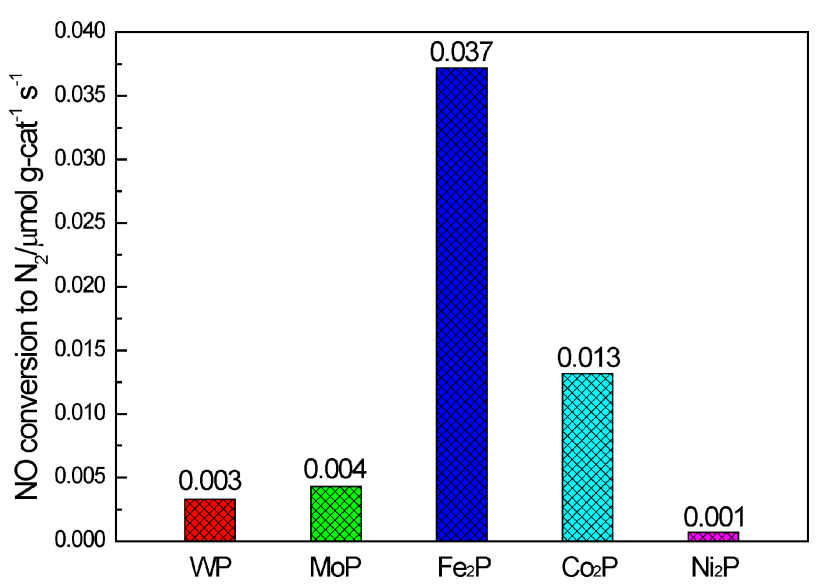

Fig. 2 - NO conversion to $N_{2}$ at $400{ }^{\circ} \mathrm{C}$ over $M o P, W P, C o_{2} P$, $\mathrm{Fe} P$ and Ni P catalysts. Reaction conditions: $N O=$ $1227 \mathrm{mg} \mathrm{m}^{-3}, W / F=1.2 \mathrm{~g} \mathrm{~s} \mathrm{~cm}^{-3}$, reaction time $=30 \mathrm{~min}$

cycle could be established by introducing a reducing agent into the system so that the oxygen could be removed to avoid bulk oxidation of phosphide catalyst. Generally, redox reaction was dependent on reaction temperature and reaction gas composition. Therefore, the rest of this paper was devoted to investigate the temperature and composition dependence of $\mathrm{NO} / \mathrm{CO}$ reaction over $\mathrm{Fe}_{2} \mathrm{P}$ catalyst, and to give insights into the genuine nature of $\mathrm{Fe}_{2} \mathrm{P}$ catalyst for catalytic removal of NO.

Table 2 lists the temperature dependence of $\mathrm{NO}$ and $\mathrm{CO}$ conversion in $\mathrm{NO} / \mathrm{CO}(1: 1$ ratio) reaction over $\mathrm{Fe}_{2} \mathrm{P}$ catalyst. It can be observed that the $\mathrm{Fe}_{2} \mathrm{P}$ catalyst showed a high activity of ca. $100 \%$ conversion of $\mathrm{NO}$ to $\mathrm{N}_{2}$ in the temperature range $300-500{ }^{\circ} \mathrm{C}$. Nevertheless, the conversion of $\mathrm{CO}$ was lower than that of NO at any temperature. The reaction we were expecting for the NO reduction with $\mathrm{CO}$ was stoichiometrically represented as:

$$
2 \mathrm{NO}+2 \mathrm{CO} \rightarrow \mathrm{N}_{2}+2 \mathrm{CO}_{2}
$$

Based on the results of TPO and $\mathrm{O}_{2}$-uptake studies ${ }^{17}$, the oxidation of $\mathrm{Fe}_{2} \mathrm{P}$ occurred above $220{ }^{\circ} \mathrm{C}$ in an oxidation atmosphere. Therefore, it was deduced that the following oxidation of $\mathrm{Fe}_{2} \mathrm{P}$ had occurred:

$$
\mathrm{Fe}_{\text {lattice }}+x \mathrm{O}_{\text {ad }} \rightarrow \mathrm{FeO}_{x}
$$

Table 2 - Temperature dependence of $N O$ and $C O$ conversion in 1:1 NO:CO reaction over Fe $P$ catalyst

\begin{tabular}{c|c|c|c}
\hline Temperature $/{ }^{\circ} \mathrm{C}$ & $\begin{array}{c}\text { Reaction } \\
\text { time/h }\end{array}$ & $\begin{array}{c}\text { NO conversion } \\
\text { to } \mathrm{N}_{2} / \%\end{array}$ & $\begin{array}{c}\mathrm{CO} \\
\text { conversion } / \%\end{array}$ \\
\hline 300 & 10 & 100 & 18 \\
400 & 32 & 100 & 70 \\
500 & 32 & 100 & 24
\end{tabular}

Reaction conditions: $\mathrm{NO}=1227 \mathrm{mg} \mathrm{m}^{-3}, \mathrm{CO}=1145 \mathrm{mg} \mathrm{m}^{-3}$, $\mathrm{W} / \mathrm{F}=1.2 \mathrm{~g} \mathrm{~s} \mathrm{~cm}^{-3}$
$\mathrm{O}_{\text {ad }}$ will be produced by $\mathrm{NO}$ dissociation.

$$
\mathrm{NO}_{\text {ad }} \rightarrow \mathrm{N}_{\text {ad }}+\mathrm{O}_{\text {ad }}
$$

Therefore, the conversion of $\mathrm{NO}$ to $\mathrm{N}_{2}$ was higher than that of $\mathrm{CO}$ because of the production of $\mathrm{N}_{2}$ during the reaction between oxygen (generated from $\mathrm{NO}$ dissociation) and $\mathrm{Fe}_{2} \mathrm{P}$ catalyst. Obviously, there was a competition between NO reduction by $\mathrm{CO}$ (Eq. 1) and $\mathrm{Fe}_{2} \mathrm{P}$ oxidation by oxygen species (Eqs. 2 and 3) in the system. The NO reduction with $\mathrm{CO}$ was an activated process, and a rise in temperature would enhance the reduction degree of NO. The CO conversion had a maximum (ca. $70 \%$ ) at $400{ }^{\circ} \mathrm{C}$, indicating that $\mathrm{NO}$ reduction degree went through a maximum at this temperature. Above $400{ }^{\circ} \mathrm{C}$, there was a sharp decrease in NO reduction probably due to the large extent of $\mathrm{Fe}_{2} \mathrm{P}$ oxidation. It was hence suggested that the addition of $\mathrm{CO}$ concentration in $\mathrm{NO} / \mathrm{CO}$ reaction at $400{ }^{\circ} \mathrm{C}$ was most likely to prevent bulk oxidation of $\mathrm{Fe}_{2} \mathrm{P}$ catalyst.

Fig. 3 shows the effect of feed composition on the catalytic activity of $\mathrm{Fe}_{2} \mathrm{P}$ catalyst in $\mathrm{NO} / \mathrm{CO}$ reactions. It can be seen that the $\mathrm{Fe}_{2} \mathrm{P}$ catalyst showed a stable activity (ca. $100 \%$ conversion of $\mathrm{NO}$ to $\mathrm{N}_{2}$ ) in a gas stream of $0.1 \% \mathrm{NO} / 0.1 \% \mathrm{CO} / \mathrm{He}$ at $400{ }^{\circ} \mathrm{C}$, but deactivated quickly after $8 \mathrm{~h}$ of onstream reaction: $\mathrm{NO}$ conversion to $\mathrm{N}_{2}$ decreased from ca. $100 \%$ to ca. $65 \%$ within a period of $11 \mathrm{~h}$. With the addition of $\mathrm{CO}$ in the feed, the $\mathrm{Fe}_{2} \mathrm{P}$ catalyst showed a stable activity throughout the test period of $11 \mathrm{~h}$, no matter whether it was in $0.1 \%$ $\mathrm{NO} / 0.2 \% \mathrm{CO} / \mathrm{He}$ or $0.1 \% \mathrm{NO} / 0.3 \% \mathrm{CO} / \mathrm{He}$. This result indicated that the lifetime of $\mathrm{Fe}_{2} \mathrm{P}$ catalyst can be prolonged when the feed gas was rich in $\mathrm{CO}$. To better analyze the effect of NO:CO compositions on the catalytic activity of $\mathrm{Fe}_{2} \mathrm{P}$ catalyst, the $\mathrm{NO}$ and

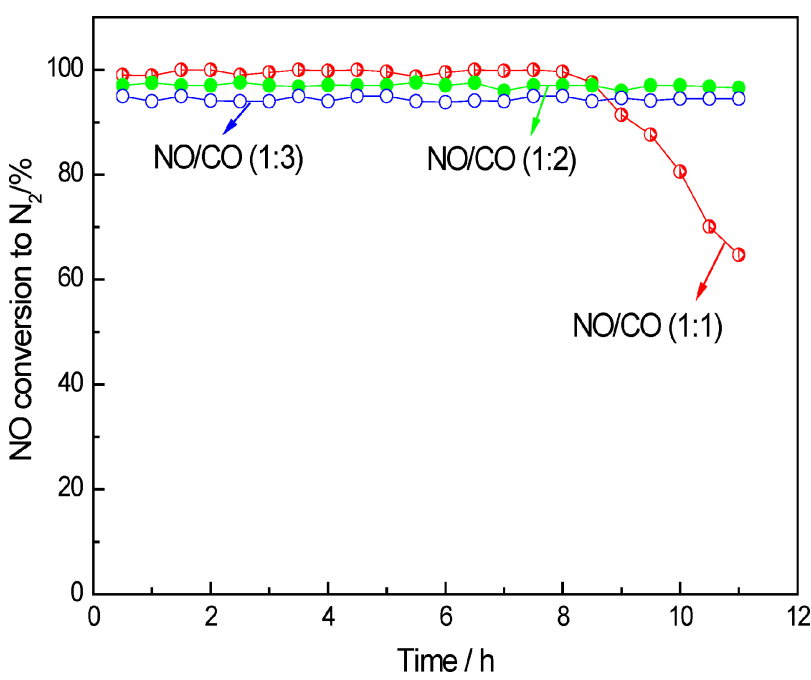

Fig. 3 - Effect of feed composition on catalytic activity of $\mathrm{Fe} P$ catalyst in NO/CO reactions. Reaction conditions: $N O=$ $1227 \mathrm{mg} \mathrm{m}^{-3}, C O=1145-3436 \mathrm{mg} \mathrm{m}^{-3}, W / F=1.2 \mathrm{~g} \mathrm{~s} \mathrm{~cm}^{-3}$, reaction temperature $=400^{\circ} \mathrm{C}$. 
Table 3 - Effect of feed composition on the catalytic activity of $\mathrm{Fe}_{2} \mathrm{P}$ catalyst in $\mathrm{NO} / \mathrm{CO}$ reactions

\begin{tabular}{c|c|c|c}
\hline CO:NO & $\begin{array}{c}\text { NO conversion } \\
\text { to } \mathrm{N}_{2} / \%\end{array}$ & $\begin{array}{c}\mathrm{CO} \\
\text { conversion } / \%\end{array}$ & $\begin{array}{c}\text { NO reduction } \\
\text { degree } / \%\end{array}$ \\
\hline $1: 1$ & 100 & 62 & 62 \\
$2: 1$ & 97 & 41 & 82 \\
$3: 1$ & 96 & 32 & 96 \\
\hline
\end{tabular}

Reaction conditions: $\mathrm{NO}=1227 \mathrm{mg} \mathrm{m}^{-3}, \mathrm{CO}=1145-3436 \mathrm{mg} \mathrm{m}^{-3}$, $\mathrm{W} / \mathrm{F}=0.15 \mathrm{~g} \mathrm{~s} \mathrm{~cm}^{-3}$, reaction time $=8 \mathrm{~h}$, reaction temperature $=$ $400{ }^{\circ} \mathrm{C}$.

$\mathrm{CO}$ conversion as well as $\mathrm{NO}$ reduction degree in $\mathrm{NO} / \mathrm{CO}$ reactions at $400{ }^{\circ} \mathrm{C}$ are shown in Table 3. The nitrogen-containing gas products was only $\mathrm{N}_{2}$, without $\mathrm{N}_{2} \mathrm{O}$ and other nitrogen oxides by analysis of MS and IRAS. Thus, the NO reduction degree can be estimated by means of $\left([\mathrm{CO}]_{\text {in }}-[\mathrm{CO}]_{\text {out }}\right) /[\mathrm{NO}]_{\text {in }}$ ratio. As shown in Table 3, the conversion of NO to $\mathrm{N}_{2}$ was closer in the three reactions. Additionally, reasonable trends can be observed that the consumption of $\mathrm{CO}$ increased when the feed composition became gradually richer in $\mathrm{CO}$, and hence the NO reduction degree correspondingly increased. This was because an addition of $\mathrm{CO}$ in feed gas could increase the $\mathrm{CO}$ concentration on the $\mathrm{Fe}_{2} \mathrm{P}$ surface, which helped in the reduction of NO by $\mathrm{CO}$ (Eq. 1), in contrast, suppressed $\mathrm{Fe}_{2} \mathrm{P}$ oxidation by surface oxygen (Eqs. 2 and 3). Note that a complete equality of NO conversion and NO reduction degree appeared to be achieved when the NO:CO ratio decreased to $1: 3$. This result indicated that the $\mathrm{CO}$ concentration in feed gas with 1:3 NO:CO ratio was sufficient to remove surface oxygen and establish a catalytic cycle on $\mathrm{Fe}_{2} \mathrm{P}$ catalyst.

In order to investigate the structural change of $\mathrm{Fe}_{2} \mathrm{P}$ catalysts after reaction, the used $\mathrm{Fe}_{2} \mathrm{P}$ catalysts (functioned in $0.1 \% \mathrm{NO} / 0.1 \% \mathrm{CO} / \mathrm{He}$ and $0.1 \%$ $\mathrm{NO} / 0.3 \% \mathrm{CO} / \mathrm{He}$, respectively, at $400{ }^{\circ} \mathrm{C}$ for $11 \mathrm{~h}$ ) were characterized by XRD. As shown in Fig. 4, the $\mathrm{Fe}_{2} \mathrm{P}$ catalyst used in $0.1 \% \mathrm{NO} / 0.1 \% \mathrm{CO} / \mathrm{He}$ for $11 \mathrm{~h}$ showed peaks of $\mathrm{Fe}_{2} \mathrm{O}_{3}, \mathrm{Fe}_{3} \mathrm{O}_{4}$ and $\mathrm{FeP}$ crystallites, and the signals of $\mathrm{Fe}_{2} \mathrm{P}$ were untraceable. This was a clear indication that bulk $\mathrm{Fe}_{2} \mathrm{P}$ can be oxidized completely by oxygen produced from NO dissociation in $0.1 \% \mathrm{NO} / 0.1 \% \mathrm{CO} / \mathrm{He}$ reaction. In other words, oxygen from $\mathrm{NO}$ dissociation would inevitably incorporate into the bulk of $\mathrm{Fe}_{2} \mathrm{P}$ catalyst and hence could be removed completely by $\mathrm{CO}$ in the feed gas. Noticeably, the diffraction pattern for the $\mathrm{Fe}_{2} \mathrm{P}$ catalyst used in $0.1 \% \mathrm{NO} / 0.3 \% \mathrm{CO} / \mathrm{He}$ for $11 \mathrm{~h}$ was identical to that of the fresh sample. These results indicated that a $\mathrm{NO} / \mathrm{CO}$ ratio of $1 / 3$ was required to avoid bulk oxidation of $\mathrm{Fe}_{2} \mathrm{P}$ catalyst in $\mathrm{NO} / \mathrm{CO}$ reaction, in good agreement with the results that a catalytic cycle can be established on

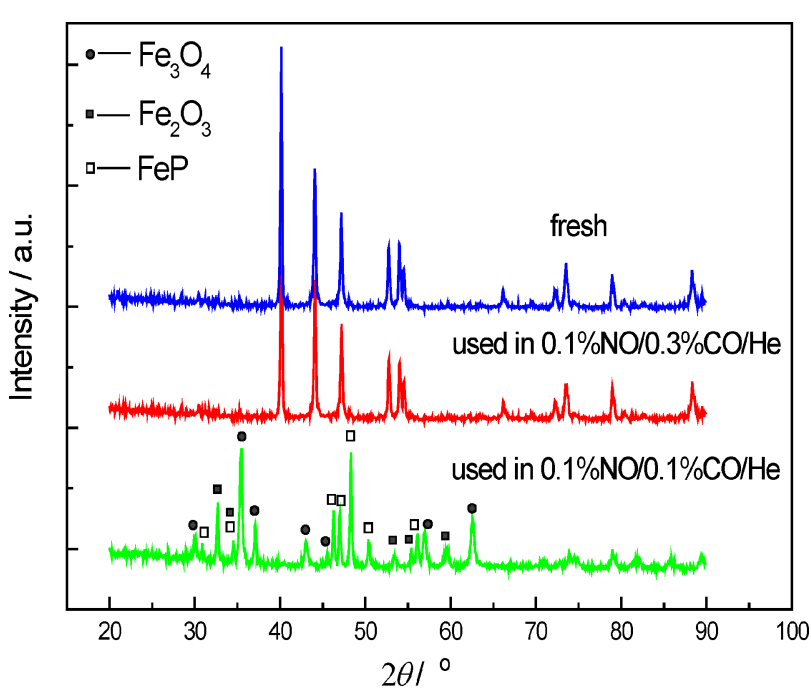

Fig. $4-X R D$ patterns of used $\mathrm{Fe}_{2} P$ samples as well as fresh sample for comparison

$\mathrm{Fe}_{2} \mathrm{P}$ catalyst in $0.1 \% \mathrm{NO} / 0.3 \% \mathrm{CO} / \mathrm{He}$ at $400{ }^{\circ} \mathrm{C}$ (Table 3).

In an attempt to understand the reaction mechanism of $\mathrm{Fe}_{2} \mathrm{P}$ catalyst for $\mathrm{NO}$ reduction with $\mathrm{CO}$, the TPSR experiment was performed to examine surface reactivity of $\mathrm{NO}$ and $\mathrm{CO}$ on $\mathrm{Fe}_{2} \mathrm{P}$ catalyst. Fig. 5 shows the MS and IRAS profiles as a function of temperature during TPSR. It can be seen that the signals of $M=30(\mathrm{NO})$ and $M=28\left(\mathrm{~N}_{2}\right.$ or CO) began to decrease when the temperature was above $\sim 220{ }^{\circ} \mathrm{C}$. This result indicated that NO and CO species adsorption and dissociation, as well as the reaction between the two species had occurred, which was in agreement with the observation of IRAS profile that $\mathrm{CO}$ concentration decreased but $\mathrm{CO}_{2}$ concentration increased above $220^{\circ} \mathrm{C}$, at the same time the production of $\mathrm{N}_{2} \mathrm{O}$ peaks occurred at $270{ }^{\circ} \mathrm{C}$. This was a clear indication that $\mathrm{NO}$ was mainly converted to $\mathrm{N}_{2} \mathrm{O}$ between 220 and $270{ }^{\circ} \mathrm{C}$. However, at temperatures above $270{ }^{\circ} \mathrm{C}$, the concentration of $\mathrm{N}_{2} \mathrm{O}$ decreased but that of $M=28\left(\mathrm{~N}_{2}\right.$ or $\mathrm{CO}$ ) increased, indicating that $\mathrm{NO}$ was mainly converted to $\mathrm{N}_{2}$. Complete NO conversion plateau was obtained at about $300^{\circ} \mathrm{C}$, which was coincident with the signal of $M=28\left(\mathrm{~N}_{2}\right.$ or $\left.\mathrm{CO}\right)$ reaching a maximum. With the temperature increased to $400{ }^{\circ} \mathrm{C}$, the signal of $M=28\left(\mathrm{~N}_{2}\right.$ or $\left.\mathrm{CO}\right)$ and the concentration of $\mathrm{CO}$ reached a lower value, but the $\mathrm{CO}_{2}$ reached the maximum concentration. This demonstrated the highest degree of $\mathrm{NO}$ reduction by $\mathrm{CO}$ (Eq. 1) at this temperature. However, the change trend of the MS and IRAS profiles above $400{ }^{\circ} \mathrm{C}$ showed a decrease in the NO reduction degree. In other words, above $400{ }^{\circ} \mathrm{C}$, the $\mathrm{Fe}_{2} \mathrm{P}$ oxidation reaction (Eqs. 2 and 3) was becoming violent. These results agreed well with the data in Table 2 . 
Based on the TPSR and XRD results, the surface reactions of $\mathrm{NO}$ and $\mathrm{CO}$ over $\mathrm{Fe}_{2} \mathrm{P}$ catalyst can be proposed as follows:

(1) $\mathrm{NO}$ dissociation and $\mathrm{Fe}_{2} \mathrm{P}$ oxidation.

$$
\begin{gathered}
\mathrm{NO}(\mathrm{g})+* \rightleftarrows \mathrm{NO} * \\
\mathrm{NO}^{*}+* \rightleftarrows \mathrm{N}^{*}+\mathrm{O} * \\
2 \mathrm{~N} * \rightleftarrows \mathrm{N}_{2} *+* \\
\mathrm{~N}_{2}^{*} \rightleftarrows \mathrm{N}_{2}(\mathrm{~g})+* \\
\mathrm{NO}(\mathrm{g})+\mathrm{NO} * \rightleftarrows \mathrm{ON} * \mathrm{NO} \\
\mathrm{ON} * \mathrm{NO}+* \rightleftarrows \mathrm{N}_{2} \mathrm{O} *+\mathrm{O} * \\
\mathrm{~N} *+\mathrm{NO} * \rightleftarrows \mathrm{N}_{2} \mathrm{O} *+* \\
\mathrm{~N}_{2} \mathrm{O} * \rightleftarrows \mathrm{N}_{2} \mathrm{O}(\mathrm{g})+* \\
x \mathrm{O} *+\mathrm{Fe}_{2} \mathrm{P} \rightarrow \mathrm{FeO}_{x}+\mathrm{FeP}
\end{gathered}
$$

In view of the fact that there was no $\mathrm{O}_{2}$ species detected in $\mathrm{NO} / \mathrm{CO}$ reaction (see Fig. 5a), it was reasonable to deduce that the oxygen produced during $\mathrm{NO}$ dissociation was partly released into the gas phase as $\mathrm{N}_{2} \mathrm{O}(\mathrm{g})$; the rest was captured by $\mathrm{Fe}_{2} \mathrm{P}$ catalyst. Heavy accumulation of surface oxygen resulted in gradual diffusion of oxygen into the $\mathrm{Fe}_{2} \mathrm{P}$ lattice, and would cause the ultimate oxidation of the bulk.

(2) NO reduction with $\mathrm{CO}$.

After introducing $\mathrm{CO}$ into the system at an appropriate reaction temperature, the poisonous effect of oxygen toward $\mathrm{Fe}_{2} \mathrm{P}$ can be eliminated by regulating the $\mathrm{CO}$ concentration in the feed; the process can be described as follows:

$$
\begin{aligned}
& \mathrm{CO}(\mathrm{g})+* \rightleftarrows \mathrm{CO}^{*} \\
& \mathrm{CO}^{*}+\mathrm{O}^{*} \rightleftarrows \mathrm{CO}_{2}^{*} \\
& \mathrm{CO}_{2}{ }^{*} \rightleftarrows \mathrm{CO}_{2}(\mathrm{~g})+*
\end{aligned}
$$

According to the results of activity studies and XRD characterization (Table 3 and Fig. 4), a minimum of $0.3 \%$ of $\mathrm{CO}$ in the $0.1 \% \mathrm{NO} / \mathrm{He}$ feed was required for establishing a catalytic cycle and avoiding bulk oxidation of $\mathrm{Fe}_{2} \mathrm{P}$ catalyst.

\section{ACKNOWLEDGMENTS}

The work was supported by the National Natural Science Foundation of China (No. 21276253 and No. 21006032).
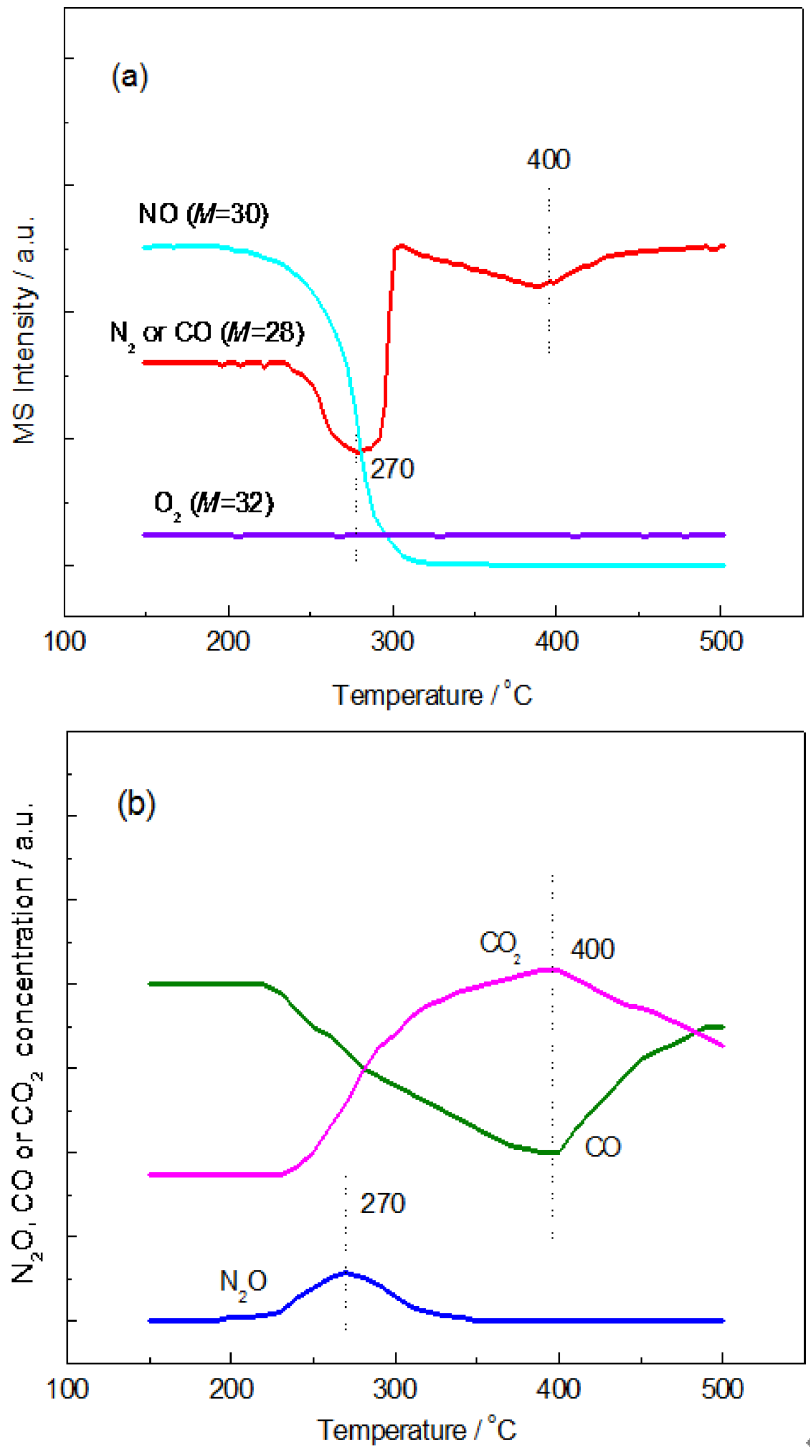

Fig. 5 - TPSR of Fe $P$ catalyst followed by (a) MS and (b) IRAS

\section{List of symbols}

$W \quad$ - weight of catalyst, $g$

$F \quad$ - flow rate of feeding gas, $\mathrm{cm}^{3} \mathrm{~min}^{-1}$

\section{References}

1. Yoon, K. Y., Jang, Y., Park, J., Hwang, Y., Koo, B., Park, $J .-G$., Hyeon, T., Synthesis of uniform-sized bimetallic iron-nickel phosphide nanorods, J. Solid State Chem. 181 (2008) 1609.

doi: http://dx.doi.org/10.1016/j.jssc.2008.05.022

2. Popczun, E. J., McKone, J. R., Read, C. G., Biacchi, A. J., Wiltrout, A. M., Lewis, N. S., Schaak, R. E., Nano structured Nickel Phosphide as an Electro catalyst for the Hydrogen Evolution Reaction, J. Am. Chem. Soc. 135 (2013) 9267. doi: http://dx.doi.org/10.1021/ja403440e

3. Jiang, X. C., Xiong, Q. H., Nam, S., Qian, F., Li, Y., Lieber, C. M., InAs/InP Radial Nanowire Heterostructures as High Electron Mobility Devices, Nano Lett. 7 (2007) 3214. doi: http://dx.doi.org/10.1021/n1072024a 
4. Alexander, A.-M., Hargreaves, J. S. J., Alternative catalytic materials: carbides, nitrides, phosphides and amorphous boron alloys, Chem. Soc. Rev. 39 (2010) 4388. doi: http://dx.doi.org/10.1039/B916787K

5. Brock, S. L., Senevirathne, K., Recent developments in synthetic approaches to transition metal phosphide nanoparticles for magnetic and catalytic applications, J. Solid State Chem. 181 (2008) 1552. doi: http://dx.doi.org/10.1016/j.jssc.2008.03.012

6. Oyama, S. T., Novel catalysts for advanced hydroprocessing: Transition metal phosphides, J. Catal. 216 (2003) 343. doi: http://dx.doi.org/10.1016/S0021-9517(02)00069-6

7. Oyama, S. T., Gott, T., Zhao, H., Lee, Y.-K., Transition metal phosphide hydroprocessing catalysts: A review, Catal. Today 143 (2009) 94. doi: http://dx.doi.org/10.1016/j.cattod.2008.09.019

8. Shu, Y., Oyama, S. T., Synthesis, characterization, and hydro treating activity of carbon-supported transition metal phosphides, Carbon 43 (2005) 1517.

doi: http://dx.doi.org/10.1016/j.carbon.2005.01.036

9. Wang, A., Ruan, L., Teng, Y., Li, X., Lu, M., Ren, J., Wang, $Y$., $H u, Y$., Hydrodesulfurization of dibenzothiophene over siliceous MCM-41-supported nickel phosphide catalysts, J. Catal. 229 (2005) 314. doi: http://dx.doi.org/10.1016/j.jcat.2004.09.022

10. Clark, P. A., Oyama, S. T., Alumina-supported molybdenum phosphide hydro processing catalysts, J. Catal. 218 (2003) 78. doi: http://dx.doi.org/10.1016/S0021-9517(03)00086-1

11. Cheng, R., Shu, Y., Zheng, M., Li, L., Sun, J., Wang, X., Zhang, T., Molybdenum phosphide, a new hydrazine de- composition catalyst: Micro calorimetry and FTIR studies, J. Catal. 249 (2007) 397.

doi: http://dx.doi.org/10.1016/j.jcat.2007.04.007

12. Ding, L., Shu, Y., Wang, A., Zheng, M., Li, L., Wang, X., Zhang, T., Preparation and catalytic performances of ternary phosphides NiCoP for hydrazine decomposition, Appl. Catal. A 385 (2010) 232. doi: http://dx.doi.org/10.1016/j.apcata.2010.07.020

13. Yang, C., Li, X., Yang, Y., Yang, X., Yang, A., Study on a New Catalyst Tungsten Phosphide for the Carbon Dioxide Reforming of Methane and Its Preparation Conditions, Asian J. Chem. 25 (2013) 3601. doi: http://dx.doi.org/10.14233/ajchem.2013.13675

14. Xiao, P., Sk, M. A., Thia, L., Ge, X., Lim, R. J., Wang, J.-Y., Lim, K. H., Wang, X., Molybdenum phosphide as an efficient electro catalyst for the hydrogen evolution reaction, Energy Environ. Sci. 7 (2014) 2624. doi: http://dx.doi.org/10.1039/C4EE00957F

15. Izhar, S., Nagai, M., Transition metal phosphide catalysts for hydrogen oxidation reaction, Catal. Today 146 (2009) 172.

doi: http://dx.doi.org/10.1016/j.cattod.2009.01.036

16. Donald, J., Xu, C., Hashimoto, H., Byambajav, E., Ohtsuka, $Y$., Novel carbon-based $\mathrm{Ni} / \mathrm{Fe}$ catalysts derived from peat for hot gas ammonia decomposition in an inert helium atmosphere, Appl. Catal. A 375 (2010) 124. doi: http://dx.doi.org/10.1016/j.apcata.2009.12.030

17. Yao, Z. W., Dong, H., Shang, Y., Catalytic activities of iron phosphide for NO dissociation and reduction with hydrogen, J. Alloys. Compd. 474 (2009) L10. doi: http://dx.doi.org/10.1016/j.jallcom.2008.06.072 